Известия Саратовского университета. Новая серия. Серия: Физика. 2021. Т. 21, вып. 1. С. $48-57$ Izvestiya of Saratov University. New Series. Series: Physics, 2021, vol. 21, iss. 1, pp. 48-57

Article

https://doi.org/10.18500/1817-3020-2021-21-1-48-57

\title{
Conductive nanofibrous scaffolds for tissue engineering
}

\author{
E. V. Lengert ${ }^{1,2}$, A. M. Pavlov ${ }^{1 凶}$
}

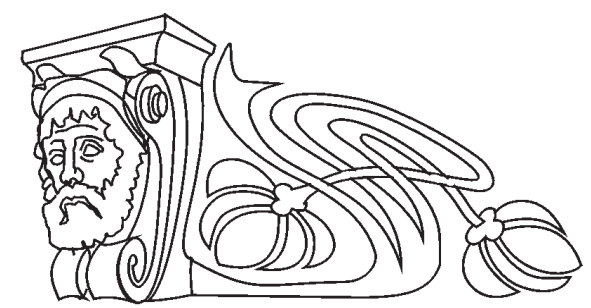

${ }^{1}$ Saratov State University, 83 Astrakhanskaya St., Saratov 410012, Russia

${ }^{2}$ Saratov State Medical University named after V. I. Razumovsky, 112 Bolshaya Kazachya, 410012 Saratov, Russia

Ekaterina V. Lengert, lengertkatrin@mail.ru, https://orcid.org/0000-0002-6447-2811

Anton M. Pavlov, pavlovam@sgu.ru, https://orcid.org/0000-0002-7999-0865

\begin{abstract}
One of very demanded and actively developed areas of modern biomedicine is tissue engineering, investigating synthesis and reparation of various kinds of tissues, including trauma treatment. Normally cells in tissue grow in the microenvironment provided by exttacellular matrix - a three-dimensional network of macromolecules, mostly peptides and proteins, that provide structural and biochemical support. To substitute this matrix in medical applications and promote new cells growth and repair damaged tissue, various types of artificial scaffolds are proposed. Morphology, as well as physical and chemical properties of scaffolds influence the fate of cells, including attachment, proliferation and differentiation, and strongly correlate with the type of target tissue. This review is aimed to provide a short insight in materials and technologies for synthesis of tissue engineering scaffolds, with focus on polymeric electrospun nonwoven materials and ones with conductive structures that can be potentially used to direct electrical signals to cells for the aims of electrostimulation, which was demonstrated to induce functional repairmen of certain cell types such as myocytes and neurons.
\end{abstract}

Keywords: tissue engineering, scaffolds, electrospinning, nanofibers

Acknowledgements: This work was supported by the Russian Science Foundation (project No. 17-79-20243).

For citation: Lengert E. V., Pavlov A. M. Conductive nanofibrous scaffolds for tissue engineering. Izvestiya of Saratov University. New Series. Series: Physics, 2021, vol. 21, iss. 1, pp. 48-57 (in English). https://doi.org/10.18500/1817-3020-2021-21-1-48-57

This is an open access article distributed under the terms of Creative Commons Attribution License (CC-BY 4.0)

Научная статья

УДК 606:616

https://doi.org/10.18500/1817-3020-2021-21-1-48-57

\section{Проводящие нановолоконные скаффолды для тканевой инженерии}

\section{Е. В. Ленгерт ${ }^{1,2}$, А. М. Павлов ${ }^{1 凶}$}

${ }^{1}$ Саратовский национальный исследовательский государственный университет имени Н. Г. Чернышевского, Россия, 410012, г. Саратов, ул. Астраханская, д. 83

${ }^{2}$ Саратовский государственный медицинский университет имени В. И. Разумовского, Россия, 410012, г. Саратов, ул. Большая Казачья, д. 112

Ленгерт Екатерина Владимировна, младший научный сотрудник, lengertkatrin@mail.ru, https://orcid.org/0000-0002-6447-2811

Павлов Антон Михайлович, старший научный сотрудник, Ph.D., pavlovam@sgu.ru, https://orcid.org/0000-0002-7999-0865

Аннотация. Одной из важных и активно развивающихся областей современной биомедицины является клеточная инженерия, исследующая вопросы выращивания новых и восстановления поврежденных тканей и органов, включая лечение травматических состояний. В природной среде клетки ткани находятся в микроокружении внеклеточного матрикса - трехмерной сети макромолеклу, в основном протеинов и пептидов, которая обеспечивает структурную и биохимическую поддержку. Для замены матрикса и поддержки роста и восстановления клеток в медицинских приложениях предложены различные типы искусственных скафаолдов. Морфология, а также физико-химические свойства скаффолдов влияют на все основные процессы в клетках, включая способность присоединяться, пролиферировать и дифференцироваться. Этот обзор призван кратко охаракеризовать существующие материалы и методы для создания скаффолдов, фокусируясь на структуры, получаемые методами электропрядения, а также скаффолды с проводящими структурами, которые могут быть использованы для передачи электрических сигналов к клеткам для их электростимуляции, которая улучшает функциональное восстановление определенных типов клеток, включая мускульные и нервные.

Ключевые слова: тканевая инженерия, скаффолды, электроспиннинг, нановолокна

Благодарности: Работа выполнена при финансовой поддержке Российского научного фонда (проект № 17-79-20243).

(C) Lengert E. V., Pavlov A. M., 2021 
Для цитирования: Lengert E. V., Pavlov A. M. Conductive nanofibrous scaffolds for tissue engineering [Ленгерт Е. В., Павлов А. М. Проводящие нановолоконные скаффолды для тканевой инженерии] // Известия Саратовского университета. Новая серия. Серия: Физика. 2021. Т. 21, вып. 1. С. 48-57. https://doi.org/10.18500/1817-3020-2021-21-1-48-57

Статья опубликована на условиях лицензии Creative Commons Attribution License (CC-BY 4.0)

\section{Introduction}

Tissue engineering is currently a field of research that attracts a huge interest worldwide. This interdisciplinary area combines cell biology, materials science and engineering to develop novel technologies for tissue and organs (re)generation [1]. The main challenge here is functional organization of individual cells into a whole system. Naturally this is performed by means of extracellular matrix which plays a prominent role in establishing and maintaining an ideal microenvironment for tissue regeneration. Here scaffolds are proposed as an artificial substitute for ECM as a feasible alternative to cellular and molecular therapy in the fields of tissue engineering. Artificial scaffolds can be divided in 3 groups based on dimensional organization and complexity, which is presented in Figure 1. Starting from isotropic simple structures (electrospun mats), scaffolds gradually evolutionate through 2D-organized structures that govern cell processes, including attachment, pro- liferation and differentiation, to the ultimate aim of complex 3D structures to reproduce whole organs.

Two approaches of tissue engineering can be distinguished. The first one is basically synthesis of a new tissue - in vitro culturing of cells tissue for subsequent implantation to the desired (damaged) site of a living organism. This method is quite complicated due to high variability of cells. Furthermore, it is quite expensive and holds a huge contamination risks upon transfer of tissues. Another way is in situ regeneration, aimed to (re)create tissues and organs in a living organism, which attracts yet growing interest for the ability to effectively control the microenvironment and localize cells to particular sites [2, 3]. This requires the presence of porous media - scaffolds - which can be easily accreted by tissue yet providing a good trophism. Such scaffolds are characterized by several properties, including porosity, pores size, mechanical properties, etc., that govern the applicability of a particular structure to certain tissue types due to a broad structural and functional variety of the latter $[4,5]$.
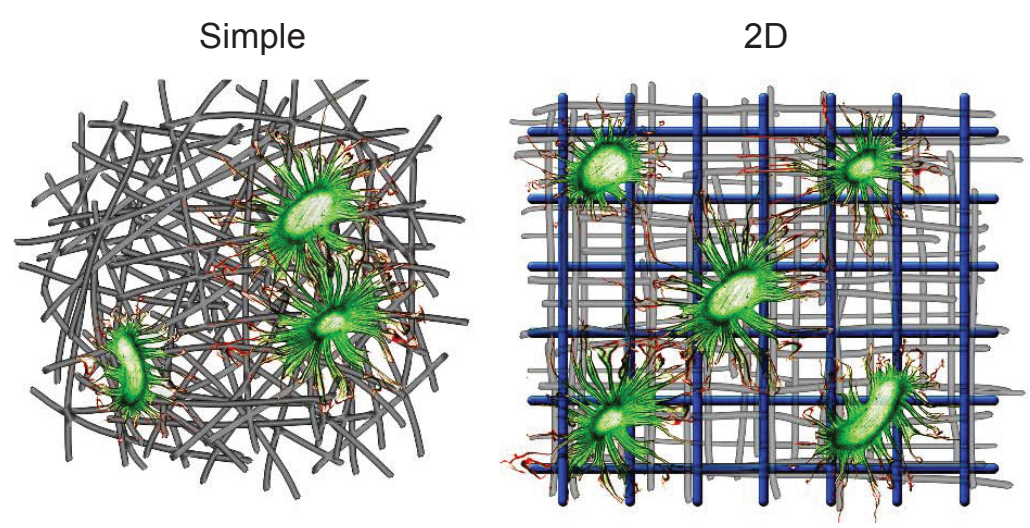

Fig. 1. Artificial scaffolds evolution

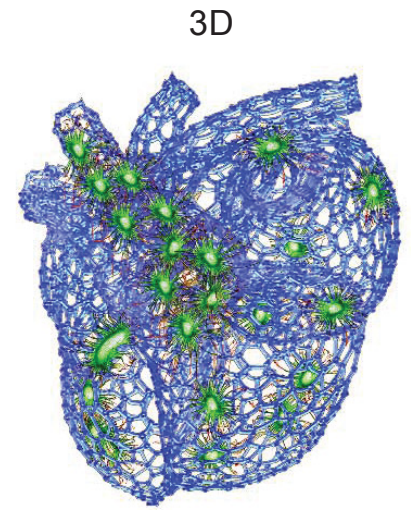

In general, scaffolds are functionalized biocompatible polymeric matrices, thus development of new materials and technologies for such structures is crucial for further progress tissue engineering, including transplantation applications. Biocompatibility and biodegradability together with good affinity to cells are among key factors that allow for the creation of a new tissue that structurally and functionally resembles the native ones [6].

Recent progress in materials science and bioengineering made the synthesis of smart scaffolds feasible [7]. Such materials are capable to restore not only the tissue defects but also the functionality lost upon the damage [8].

A number of methods were developed for scaffolds preparation, including solvent casting/particulate leaching [9], freeze-drying [10], gas foaming [11], thermally induced phase separation [12], and electrospinning, which seems to be among the most popular ones recently [13]. Further introduction of biomimetic and bioactive properties can be achieved by functionalization. Combined with an appropriate choice of 
materials and synthesis technologies, which influence the morphology and mechanical properties of the resulting medium, this creates an advantageous approach for a variety of tissue engineering applications.

During recent decades, a perspective strategy of scaffolds usage with seed cells (mostly chondrocytes) for regeneration of damaged cartilage was reported. Culturing of chondrocytes in 2D and 3D artificial matrix and in vivo regeneration of cartilage tissue was reported [14]. Sherwood et al. proved efficiency of a composite scaffold obtained with TheriForm ${ }^{\mathrm{TM}}$ 3D printing process for articular cartilage repair. Tissueengineered bone constructs have the potential to alleviate the demand arising from the shortage of suitable autograft and allograft materials for augmenting bone healing. Scaffolds play a key role in tissue engineering research as these not only provide a structural support for individual cells, but also serve as templates that guide the growth and buildup of new tissues [15].

For some cell types, such as in neural tissue, a successful scaffold should consist of aligned fibers due to topological signals that are sensed by cells and influence adhesion, proliferation and migration, thus determining neurons growth from stem cells. Scaffolds for Schwann cells [16] as well as spinal ganglion [17] were reported. Promoted regeneration of sciatic nerve gaps in rats using $3 \mathrm{D}$ porous tissue scaffolds was demonstrated [18].

In electro sensitive cells such as neural, cardio and muscular tissues, bioelectricity plays an important role in cells vital functions. Here, conductive scaffolds can be advantageous for rehabilitation of tissue functionality, neurites growth and proliferation enhancement, as well as neurons regeneration by stimulation with externally applied cycled voltage [19].

Electric stimulation is a relatively simple flexible method of functional regeneration applicable to 2D and 3D cells structures in vitro and in vivo [20]. Electrical current between two externally applied electrodes can influence the behavior of cells being treated by membrane depolarization and subsequent intracellular processes that rely on charged ions generation and movements [21]. The use of conductive scaffolds for electrostimulation is a relatively new promising approach to influence regeneration of axons, cells migration and neural differentiation [22].

While numerous types of scaffolds are reported, a successful formation of such structures with desired structural properties and biological functions remains a problem which renders both materials and technological challenges [23]. Here we aim to present a short review of recently proposed designs of polymeric scaffolds based on nonwoven fibrous materials, including ones capable of transmitting electrical impulses that can be used for functional rehabilitation of electrosensitive tissues to overcome limitations of current treatments methods.

\section{Materials for scaffolds}

Scaffolds for tissue engineering have to be non-toxic to cells and surrounding tissues, provide two-way diffusion for nutritional and metabolite species and possess enough structural strength to sustain mechanical stresses associated with in vivo implantation [4].

A variety of natural and synthetic materials is utilized for scaffolds generation. Synthetic ones include poly(ethylene oxide), poly(vinyl alcohol) (PVA), poly(acrylic acid), poly(propylene furmarateco-ethylene glycol) and polypeptides. Representative naturally derived polymers include agarose, alginate, chitosan, collagen, fibrin, gelatin, and hyaluronic acid [24]. Biodegradable polymers such as polylactic (PLA) and polyglycolic acids (and copolymers of those) are actively utilized for good mechanical properties and control over degradation rate [25]. Recently, in vitro and in vivo testing of selective laser melted porous Ti6A14V extra low interstitials (ELI, grade 23) alloy scaffolds for bone implantation was performed, where tissue proliferation, differentiation and bone regeneration were studied against scaffold porosity [26]. A short summary of materials that are used for scaffolds preparation is presented in Table 1.

Various inclusions into polymeric matrix provide a powerful and convenient control over additional functions and properties of resulting scaffolds, which allows for fitting the structures to particular applications. Lee et al. proposed hybrid gelatin methacryloyl hydrogels with various carbon particles (nanotubes, graphene oxide and reduced graphene oxide) for cardiac tissue. It was shown that amount of conductive particles drastically influences mechanical and electrophysical properties of resulting structures [27].

Polymer-ceramics composites were utilized to enhance mechanical properties of polymers and induce cellular adhesion [28-30]. Natural materials such as polysaccharides (starch, alginate, chitosan, hyaluronic acid) and proteins (collagen, fibrin gels, silk) were also reported to induce cells proliferation [31-36].

Hydrogels attract significant attention for their ability to retain water which can be demanded for cells delivery and encapsulation in scaffolds [33, 37]. For electrosensitive tissues, composite hydrogels are developed, that consist of structural support and conductive components [38]. 
Summary of materials used for scaffolds assembly

\begin{tabular}{|c|c|c|c|c|}
\hline & Materials & Usage & Advantages & Disadvantage \\
\hline \multirow{5}{*}{$\begin{array}{l}\bar{\pi} \\
\text { 吾 } \\
\text { Z }\end{array}$} & Collagen & $\begin{array}{l}\text { Tendon/ligament tissue repair, } \\
\text { stimulates proliferation and } \\
\text { differentiation }\end{array}$ & \multirow[t]{2}{*}{$\begin{array}{l}\text { Biocompatible, implantable, } \\
\text { resorbable, supports new tissue } \\
\text { regeneration and protects the } \\
\text { chondral surfaces. }\end{array}$} & \multirow[t]{3}{*}{$\begin{array}{l}\text { Scaffold shrinkage after } \\
\text { long-term culturing and poor } \\
\text { mechanical properties }\end{array}$} \\
\hline & Gelatin & Tissue regemeration & & \\
\hline & Fibrin & $\begin{array}{l}\text { Tissue regeneration, spinal } \\
\text { cord injury repairmen }\end{array}$ & $\begin{array}{l}\text { High seeding efficiency } \\
\text { and uniform cell distribution, } \\
\text { good adhesion capabilities. }\end{array}$ & \\
\hline & Alginate & $\begin{array}{l}\text { Wound healing, cartilage and } \\
\text { bone tissue regeneration, drug } \\
\text { delivery }\end{array}$ & $\begin{array}{l}\text { Antimicrobial activity, } \\
\text { mucoadhesiveness, hemostatic } \\
\text { activity, biocompatibility, } \\
\text { and biodegradability }\end{array}$ & Poor mechanical properties \\
\hline & Chitosan & $\begin{array}{l}\text { Coatings for a variety of } \\
\text { scaffolds for wound dressings } \\
\text { skin substitutes, tissue } \\
\text { engineering }\end{array}$ & & $\begin{array}{l}\text { Not stable (uncontrolled } \\
\text { dissolution may occur), } \\
\text { low mechanical resistance }\end{array}$ \\
\hline \multirow{3}{*}{ 囦 } & $\begin{array}{l}\text { Synthetic } \\
\text { fiber- } \\
\text { reinforced }\end{array}$ & $\begin{array}{l}\text { Cartilage, vascular, skin, } \\
\text { bone, tendon, ligament tissues } \\
\text { repair }\end{array}$ & $\begin{array}{l}\text { Biocompatibility, mechanical } \\
\text { stability and commercial } \\
\text { availability, efficient cell } \\
\text { proliferation and osteogenic } \\
\text { differentiation }\end{array}$ & $\begin{array}{l}\text { Low fracture toughness } \\
\text { (i.e., brittleness), mechanical } \\
\text { properties might be poor }\end{array}$ \\
\hline & $\begin{array}{l}\text { Polyglycolic } \\
\text { acids } \\
\text { (PLGA) }\end{array}$ & Tissue engineering & $\begin{array}{l}\text { Adjustability of degradation } \\
\text { rates, good mechanical properties } \\
\text { especially toughness }\end{array}$ & $\begin{array}{l}\text { Harsh organic solvents, higly } \\
\text { acidic degradation byproducts } \\
\text { which are hard to metabolize } \\
\text { rapidly }\end{array}$ \\
\hline & $\begin{array}{l}\text { Poly } \\
\text { (L-lactic } \\
\text { acid) }\end{array}$ & $\begin{array}{l}\text { Biomedical applications, } \\
\text { such as sutures, scaffolds for } \\
\text { tissue engineering, and drug } \\
\text { delivery systems }\end{array}$ & $\begin{array}{l}\text { Good solubility and blending } \\
\text { compatibility with other } \\
\text { biomaterials }\end{array}$ & $\begin{array}{l}\text { Harsh organic solvents, low } \\
\text { cell adhesion and degradation } \\
\text { rate due to hydrophobicity, } \\
\text { biological inertness, and } \\
\text { possible inflammations die to } \\
\text { acidic degradation products }\end{array}$ \\
\hline
\end{tabular}

Collagen/PCL nanofibers were shown to have better results in terms of glia attachment and axons migration and growth as compared to just PCL materials for neurites growth [39] or PLA [40]. Proteins like laminin (which is secreted upon nerve damage and plays a key role in cells migration, differentiation and growth) can be introduced to the system to control the tissue reparation [41]. To perform electrostimulation, conductive polymers such as polypyrrole (PPy) [42], polythiophene [43], polyaniline (PANi), poly $(3,4-$ ethylenedioxythiophene) (PEDOT) and polycaprolactone fumarate [44] can be utilized [19]. While conductive polymers lack degradability, which can lead to inflammations and need surgical extraction, these can be mixed with biodegradable ones, resulting in an electroactive composite, such as low molecular weight aniline pentamer/polylactide [45].

\section{Scaffolds designs}

One of most popular methods for scaffolds synthesis is electrospinning which is a well established technique for single-stage relatively low cost (at lab scale) nonwoven mats deposition [46]. Electrospun mats can mimic natural extracellular matrix by variation of fibers diameters (and, therefore, pores size) and high surface to volume ratio which helps adhesion and nutrition transportation [47]. At the same time, electrospinning process has its limitations induced by use of high voltage and mostly toxic solvents [48]. Torricelli et al. demonstrated coaxial-needle electrospun gelatin-PLA material for in vitro chondrocytes culturing [49]. Gelatin was cross-linked with genipin for enhanced mechanical properties and primary human chondrocytes adhesion. Good proliferation and increased values of the differentiation parameters 
together with cells infiltration through the material were demonstrated. Successful mineralization of scaffolds with a uniform layer of poorly crystalline apatite onto the scaffolds suggested potential applications involving cartilage as well as cartilage-bone interface tissue engineering.

PVA based nanofibers seem promising for skin, cartilage and corneal tissue engineering [50]. Sadeghi et al. [51] reported biocompatible PVA/ gelatin/chondroitin sulfate electrospun. Concentration of $50 \%$ of acetic acid in water was found to be the most appropriate for solvent, while polymer concentration was varied in range of $8-10 \%$ vol. Gradual electrospinning process resulting in mats without beads was achieved at solution flow rate of $1-1.4 \mathrm{~mL} / \mathrm{h}$ and voltage of $20-26 \mathrm{kV}$. L929 murine fibroblast cells were shown to have a good adhesion and proliferation to the substrate (Fig. 1) [51].

Migration of cells through the material requires a balance between cells and matrix dimensions and morphology. This was demonstrated on Human umbilical cord mesenchymal stem cells (hucMSC) and polycarbonate membrane with pores size of $0.4,3.0$ and $8 \mu \mathrm{m}$ (migrations of $0,1.8$ and $8 \mu \mathrm{m}$ were observed, respectively). Migration of polymorphonuclear neutrophils was restrained by 90 and $99 \%$ using polycarbonate membrane with pores of $1.49-1.78$ and $1.26-1.38 \mu \mathrm{m}$, respectively [52]. However, feasibility of stem cells migration stimulation across $2 \mathrm{D}$ scaffold was demonstrated. It was shown that hMSCs migration through the membrane pores of $8 \mu \mathrm{m}$ in diameter was more efficient when the normal dermal fibroblasts were replaced by the keloid-derived ones on the bottom of a dual-modified Boyden chamber. The hMSCs were able to migrate across the membrane with $3 \mu \mathrm{m}$ pores only when the same keloid-derived fibroblasts were placed on the bottom of the plates [53].

Cells infiltration was found to increase with pores size of PCL scaffold (governed by fibers diameter, varied with concentration of polymer in electrospinning solution) [54]. Maximum infiltration was achieved when pores size was about the cells dimensions. It is important, however, that overall optimum scaffold performance in vivo cannot be achieved in scaffolds with fibers diameter equal to the cells dimensions [55]. For Ti6A14V ELI alloy scaffolds for bone implantation, best tissue proliferation, osteogenic differentiation and bone regeneration were achieved in scaffolds with pores size of $500 \mu \mathrm{m}$ and porosity of $60 \%$ [26].

Soft tissue engineering is a regeneration strategy for damaged sites and organs that is promising to overcome limitations of existing treatment approaches. Most of soft tissues are structurally held with collagen fibers forming a spatial structure (extracellular matrix). Scaffolds are designed as a substitute to this, providing space and ability for regeneration and remodeling [56] and act as a bridge to fill spaces and therefore connecting damaged tissues, including peripheral nerve regeneration [57].

When functionalized with biomimetic coating, electrospun scaffolds are able to provide both mechanical structure and an appropriate physicochemical environment, as it was demonstrated for bone matrix [58] (Fig. 2).
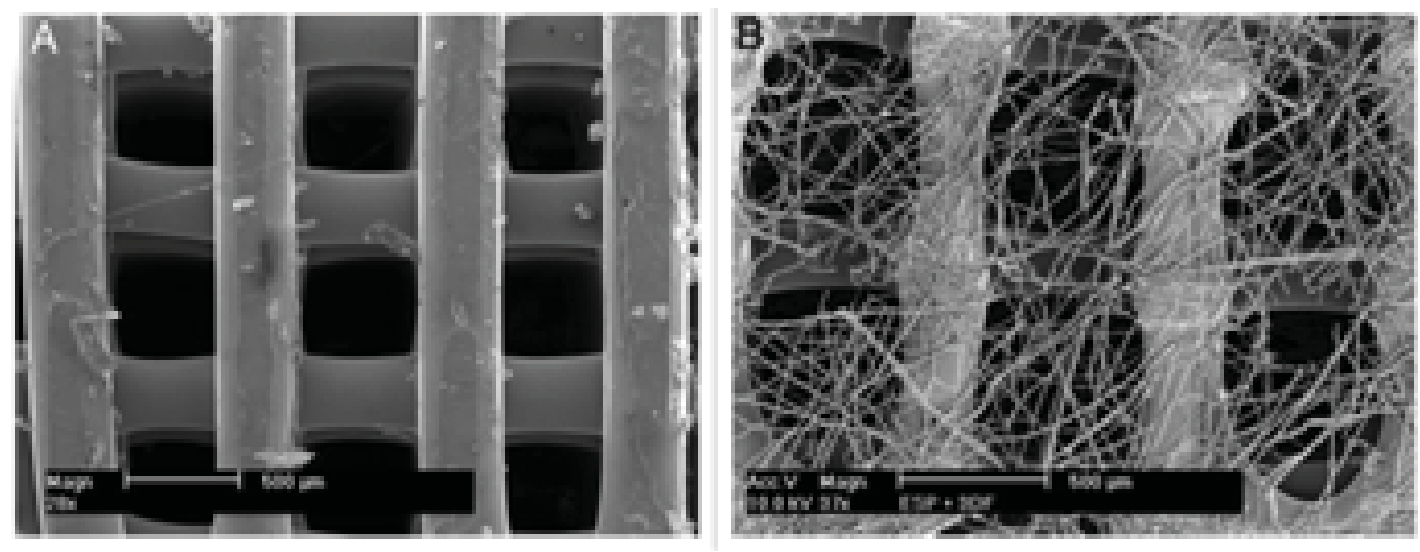

Fig. 2. Scaffold morphology using SEM (A) 3DF scaffold prepared by rapid prototyping. (B) 3DF + ESP scaffold prepared by combining rapid prototyping and electrospinning. The scaffold has been "opened" to enable visualization of the electrospun fiber meshes. Scale bar $=500 \mu \mathrm{m}$ (image reproduced from Nandakumar et al., with permission Biomatter [58, e23705-3]) 


\section{Scaffolds for electrical stimulation}

Electrical stimulation in the form of pulsed voltage applied to cells finds its applications in tissue engineering and clinic, mostly for post-traumatic neuronal rehabilitation, but including wound treatment, chronic and acute pain relief, and also treatment of neurodegenerative conditions such as Parkinson's disease [21].

Importance of dielectric scaffolds and surfaces as control elements in studies of electric signals transport by ionic conductivity in neuronal cultures for designing new culturing approaches including conductive scaffolds was demonstrated. Particularly, differentiation of PC12 cells was studied on microfibrous scaffolds immersed into culturing medium and underwent exogenous electrostimulation. Two types of scaffolds were used - dielectric and coated with $200 \mathrm{~nm}$ layer of gold (resistivity of $13 \Omega \cdot \mathrm{cm}^{-1}$ ). Stimulation significantly induced growth and attachment of cells in dielectric scaffolds in contrast to conductive ones. Differentiation of cells enhanced upon stimulation in both cases, while neurites development and differentiation markers expression was higher in dielectric scaffolds [59]. This suggests that electrical potential difference may be the dominant driver of the observed changes rather than current. However, because the nature of the currents generated in the two scaffold systems was not the same, the situation is more equivocal. For the scaffolds with gold where the scaffold and medium acted as two electrical resistances in parallel, because the resistance of the scaffold was much lower than that of the medium, most of the current flowed as free electrons through the metallic gold and only a very small proportion was transmitted by ionic migration. In contrast, for the nonconductive scaffolds without gold, ionic migration in the medium was responsible for all of the $8-9 \mu \mathrm{A}$ of current observed. It is possible therefore that electrical current is an important driver of cell behaviour but was much more effective in the ionic rather than electron form.

Conductive scaffolds can be applied to form a desired morphology of cardiomyocytes and induce expression of functional cardiac markers. Fibrous membranes prepared by rotational electrospinning from polyurethane and gelatin were studied recently by Rodrigues et al. [60] to show good viability of endothelial cells during 72 hours.

Three-dimensional scaffolds were also proposed for reconstruction of skeletal muscles, which are electroactive tissue with complicated internal morphology that is tightly dependent on extracellular matrix interactions. Polyurethane soft porous scaffold ( $86 \%$ porosity) with Young's modulus value close to that of natural tissue ( $\sim 9 \mathrm{kPa}$ ) were reported by Iberite et al. [61]. To study the influence of external stimuli on muscular cells, functionalized scaffolds with natural extracellular matrix proteins (laminin and fibronectin) were used to observe enhanced proliferation of myoblasts, additional stimulation of tissue on a laminine-coated scaffold resulted in more spread and thicker myotubes compared to non-stimulated samples and samples receiving the single (non-combined) inputs [61].

Composite conductive scaffolds of poly(lacticco-glycolic acid) modified with multiwall carbon nanotubes were demonstrated to direct the growth of PC12 cells and DRG neurons along the fibers. Neuronal differentiation was also shown to be higher with exogenous electrical stimulation [62]. Human endometrial stem cells were shown to attach, proliferate, and differentiate into neural cells on electrospun PAN-derived carbon nanofibers obtained by carbonization. Proliferation and markers expression was found to be dependent on alignment of the fibers [63]. Fibers were electrospun from polyacrylonitrile solution in N,N-dimethylfromamide and terephthalic acid at voltage $10 \mathrm{kV}$ over distance of $10 \mathrm{~cm}$. For alignment, fibers were collected on the spinning rotor. After carbonization, scaffolds had good electrical properties while sustaining great flexibility. Electrical stimulation allowed for further enhancement of control over proliferation and differentiation of neuronal stem cells using this new scaffolds [64].

Neuronal differentiation of conjunctiva derived mesenchymal stem cells was studied recently on conductive 3D electrospun scaffolds prepared of silk fibroin and reduced graphene oxide. Graphene oxide (3.5 $\mathrm{wt} \%$ ) was dispersed in $10 \%$ polymer solution in formic acid. Cells were cultured on scaffold and stimulated at electric field of $115 \mathrm{~V} / \mathrm{m}$ in two pulse regimes of 0.1 and $100 \mathrm{~Hz}$ during 7 days. It was found that pulse frequency plays a significant role in cellular fate [65].

Scaffolds utilizing conductive polymers are also intensively developed. Laforgue et al. reported successful ultrathin coating of PPy and PEDOT onto electrospun PANi nanofibers using vapor-phase polymerization [66]. Coating thickness was $5-12 \mathrm{~nm}$ which provided conductivity of $1-26 \mathrm{Sm} \cdot \mathrm{cm}^{-1}$.

Ling Wang et al. demonstrated conductive electrospun scaffolds of PLA/PANi with fibers thickness allowing for maintaining conductive biocompatible microenvironment for proliferation, development and synchronized triggering of cardiomyocytes which shows a great potential of conductive nanofibrous scaffolds for cardio-related tissue engineering [67]. 
Laleh Ghasemi-Mobarakeh et al. utilized DC power supply to stimulate neournal stem cells on scaffold prepared by mixing 10 and $15 \mathrm{wt} \%$ doped PANi with poly ( $\varepsilon$-caprolactone)/gelatin (70:30) solution by electrospinning.

In vitro studies with neuronal stem cells on these scaffolds with applied voltage of $1.5 \mathrm{~V}$ for up to 60 minutes starting from 24 hours since seeding [68]. This time frame was used as previous studies shown efficiency of electrostimulation during first 24 hours of growth, while stimulation beyond this time interval had no sufficient effect on cells proliferation and differentiation as compared to control samples [69]. The voltage difference per unit distance on $15 \mathrm{~mm}$ scaffolds was equivalent to $100 \mathrm{mV} / \mathrm{mm}$ which should be sufficient for successful stimulation $[68,70]$. Control experiments were performed where neuronal stem cells were seeded to PANI-PG scaffolds without stimulation. No significant difference was found in neurites length between samples for stimulation duration up to 30 minutes. After $1 \mathrm{~h}$ long stimulation, neurites length was 30 and $22 \mu \mathrm{m}$ for stimulated and control samples, respectively [68].

However, the main challenging problem with using conductive polymers for scaffolds is the toxicity of residual dopants. Hardly feasible, complete removal of these will inevitably drastically compromise physical-chemical and electrical properties of resulting structures.

\section{Conclusions}

With development of new treatment methods of modern medicine and biochemistry that provide better understanding of intra- and extracellular processes more various kinds of implants will be proposed. Scaffolds for tissue engineering are essentially such type of implants that can be fitted to particular application, depending on target tissue type and allocation. For soft tissues scaffolds, polymers are a natural material provided by affinity of mechanical properties. Besides, a wide set of methods exists to functionalize polymeric structures with a variety of objects from small and large molecules to nanoparticles and coatings, and it seems the main direction for development in this area.

Combined methods are also developed for cell types which are able to receive other stimuli besides scaffold morphology and chemistry, such as electrosensitive cells, which demands designing of special structures that comply with the application and define the directions for further technological development in this area.
Overall, tissue scaffolds originated from the need to replace rigid simple culturing chambers and slides to biomimetic surfaces that can be potentially applied for in vivo connected manipulations. With huge variability and functionalization capacity, polymeric materials are an obvious choice for such structures, with electrospinning technology providing a good structural design that can be tailor-fitted towards particular needs. Scaffolds inevitably evolve in functions and complexity together with new materials and technological approaches. From materials point of view, combination of biochemical and mechanical properties in one structure remains the biggest challenge for scaffolds to substitute natural extracellular matrix that can provide tissue with everything it needs for development, including structural support, nutrition and varios biological factors for attachment, migration, differentiation, etc. Despite a wide choice of polymers and other chemicals, combination of desired properties in a cocktail of species which is biofriendly at all stages is still quite complicatied if possible. Introduction of physical functions such as electrostimulation which is benefitial for certain tissues, brings in even more technological and chemical problems to be solved for successful broad applications of artificial scaffolds in real-life regenerative medical treatment. With ultimate aim of organ-like structures, scaffolding also needs technologies to create porous structures that can be settled by cells to become viable 3D-organized tissues, so there is still a long and fascinating road ahead.

\section{References}

1. Akbari M., Tamayol A., Bagherifard S., Serex L., Mostafalu P., Faramarzi N., Mohammadi M. H., Khademhosseini A. Textile Technologies and Tissue Engineering: A Path Toward Organ Weaving. Advanced Healthcare Materials, 2016, vol. 5, iss. 7, pp. 751-766. https://doi. org/10.1002/adhm.201500517

2. Lee S. J., Yoo J. J., Atala A. Fundamentals of In Situ Tissue Regeneration. In: In Situ Tissue Regeneration. Elsevier, 2016, pp. 3-17.

3. Jiao Y., Li C., Liu L., Wang F., Liu X., Mao J., Wang L. Construction and application of textile-based tissue engineering scaffolds: A review. Biomaterials Science, 2020, vol. 8, iss. 13, pp. 3574-3600. https://doi.org/10.1039/ D0BM00157K

4. Sun A. M., Vacek I., Tai I. Microencapsulation of Living Cells and Tissues. In: M. Donbrow, ed. Microcapsules and Nanoparticles in Medicine and Pharmacy. CRC Press, 1992, pp. 315-322.

5. Feng P., He J., Peng S., Gao C., Zhao Z., Xiong S., Shuai C. Characterizations and interfacial reinforcement mechanisms of multicomponent biopolymer based scaffold. 
Materials Science and Engineering: C, 2019, vol. 100, pp. 809-825. https://doi.org/10.1016/j.msec.2019.03.030

6. Grayson W. L., Martens T. P., Eng G. M., Radisic M., Vunjak-Novakovic G. Biomimetic approach to tissue engineering. Seminars in Cell \& Developmental Biology, 2009, vol. 20, iss. 6, pp. 665-673. https:// doi.org/10.1016/j.semcdb.2008.12.008

7. Dvir T., Timko B. P., Kohane D. S., Langer R. Nanotechnological strategies for engineering complex tissues. Nature Nanotechnology, 2011, vol. 6, iss. 1, pp. 13-22. https://doi.org/10.1038/nnano.2010.246

8. Custódio C. A., Reis R. L., Mano J. F. Engineering Biomolecular Microenvironments for Cell Instructive Biomaterials. Advanced Healthcare Materials, 2014, vol. 3, iss. 6, pp. 797-810. https://doi.org/10.1002/ adhm.201300603

9. Hou Q., Grijpma D. W., Feijen J. Porous polymeric structures for tissue engineering prepared by a coagulation, compression moulding and salt leaching technique. Biomaterials, 2003, vol. 24, iss. 11, pp. 1937-1947. https://doi.org/10.1016/S0142-9612(02)00562-8

10. Fereshteh Z., Fathi M., Bagri A., Boccaccini A. R. Preparation and characterization of aligned porous $\mathrm{PCL} /$ zein scaffolds as drug delivery systems via improved unidirectional freeze-drying method. Materials Science and Engineering: C, 2016, vol. 68, pp. 613-622. https://doi.org/10.1016/j.msec.2016.06.009

11. Kim S.-S., Sun Park M., Jeon O., Yong Choi C., Kim B.-S. Poly(lactide-co-glycolide)/hydroxyapatite composite scaffolds for bone tissue engineering. Biomaterials, 2006, vol. 27, iss. 8, pp. 1399-1409. https://doi.org/10.1016/j. biomaterials.2005.08.016

12. Lou T., Wang X., Song G., Gu Z., Yang Z. Fabrication of PLLA/ $\beta$-TCP nanocomposite scaffolds with hierarchical porosity for bone tissue engineering. International Journal of Biological Macromolecules, 2014, vol. 69, pp. 464-470. https://doi.org/10.1016/j.ijbiomac.2014.06.004

13. Bao M., Lou X., Zhou Q., Dong W., Yuan H., Zhang Y. Electrospun Biomimetic Fibrous Scaffold from Shape Memory Polymer of PDLLA- co -TMC for Bone Tissue Engineering. ACS Applied Materials \& Interfaces, 2014, vol. 6, iss. 4, pp. 2611-2621. https://doi.org/10.1021/ am $405101 \mathrm{k}$

14. Sliogeryte K., Botto L., Lee D. A., Knight M. M. Chondrocyte dedifferentiation increases cell stiffness by strengthening membrane-actin adhesion. Osteoarthritis and Cartilage, 2016, vol. 24, iss. 5, pp. 912-920. https:// doi.org/10.1016/j.joca.2015.12.007

15. Shadjou N., Hasanzadeh M., Khalilzadeh B. Graphene based scaffolds on bone tissue engineering. Bioengineered, 2018, vol. 9, iss. 1, pp. 38-47. https://doi.org/10.1080/ 21655979.2017.1373539

16. Ning L., Sun H., Lelong T., Guilloteau R., Zhu N., Schreyer D. J., Chen X. 3D bioprinting of scaffolds with living Schwann cells for potential nerve tissue engineering applications. Biofabrication, 2018, vol. 10, iss. 3, pp. 035014. https://doi.org/10.1088/1758-5090/aacd30

17. Balgude A. Agarose gel stiffness determines rate of DRG neurite extension in 3D cultures. Biomaterials, 2001, vol. 22, iss. 10, pp. 1077-1084. https://doi.org/10.1016/ S0142-9612(00)00350-1
18. Gu Y., Zhu J., Xue C., Li Z., Ding F., Yang Y., Gu X. Chitosan/silk fibroin-based, Schwann cell-derived extracellular matrix-modified scaffolds for bridging rat sciatic nerve gaps. Biomaterials, 2014, vol. 35, iss. 7, pp. 2253-2263. https://doi.org/10.1016/j.biomaterials.2013.11.087

19. Zha F., Chen W., Zhang L., Yu D. Electrospun natural polymer and its composite nanofibrous scaffolds for nerve tissue engineering. Journal of Biomaterials Science, Polymer Edition, 2020, vol. 31, iss. 4, pp. 519-548. https:// doi.org/10.1080/09205063.2019.1697170

20. Sun S., Titushkin I., Cho M. Regulation of mesenchymal stem cell adhesion and orientation in 3D collagen scaffold by electrical stimulus. Bioelectrochemistry, 2006, vol. 69, iss. 2, pp. 133-141. https://doi.org/10.1016/j. bioelechem.2005.11.007

21. Ghasemi-Mobarakeh L., Prabhakaran M. P., Morshed M., Nasr-Esfahani M. H., Baharvand H., Kiani S., AlDeyab S. S., Ramakrishna S. Application of conductive polymers, scaffolds and electrical stimulation for nerve tissue engineering. Journal of Tissue Engineering and Regenerative Medicine, 2011, vol. 5, iss. 4, pp. e17-e35. https://doi.org/10.1002/term.383

22. Huang Y., Li Y., Chen J., Zhou H., Tan S. Electrical Stimulation Elicits Neural Stem Cells Activation: New Perspectives in CNS Repair. Frontiers in Human Neuroscience, 2015, vol. 9, pp. 1-9. https://doi.org/10.3389/ fnhum. 2015.00586

23. Ning L., Chen X. A brief review of extrusion-based tissue scaffold bio-printing. Biotechnology Journal, 2017, vol. 12, iss. 8, pp. 1600671. https://doi.org/10.1002/ biot. 201600671

24. Drury J. L., Mooney D. J. Hydrogels for tissue engineering: Scaffold design variables and applications. Biomaterials, 2003, vol. 24, iss. 24, pp. 4337-4351. https://doi. org/10.1016/S0142-9612(03)00340-5

25. Dorati R., DeTrizio A., Modena T., Conti B., Benazzo F., Gastaldi G., Genta I. Biodegradable Scaffolds for Bone Regeneration Combined with Drug-Delivery Systems in Osteomyelitis Therapy. Pharmaceuticals, 2017, vol. 10, iss. 4, pp. 96. https://doi.org/10.3390/ph10040096

26. Chen Z., Yan X., Yin S., Liu L., Liu X., Zhao G., Ma W., Qi W., Ren Z., Liao H., Liu M., Cai D., Fang H. Influence of the pore size and porosity of selective laser melted Ti6Al4V ELI porous scaffold on cell proliferation, osteogenesis and bone ingrowth. Materials Science and Engineering: C, 2020, vol. 106, pp. 110289. https://doi. org/10.1016/j.msec.2019.110289

27. Lee J., Manoharan V., Cheung L., Lee S., Cha B.-H., Newman P., Farzad R., Mehrotra Sh., Zhang K., Khan F., Ghaderi M., Yi-Dong Lin, Aftab S., Mostafalu P., Miscuglio M., Li J., Biman B. Mandal, Mohammad Asif Hussain, Kai-tak Wan, Xiaowu Shrley Tang, Ali Khademhosseini, Su Ryon Shin. Nanoparticle-Based Hybrid Scaffolds for Deciphering the Role of Multimodal Cues in Cardiac Tissue Engineering. ACS Nano, 2019, vol. 13, iss. 11 , pp. 12525-12539. https://doi.org/10.1021/ acsnano.9b03050

28. Ma P., Wei G. Polymer/Ceramic Composite Scaffolds for Bone Tissue Engineering. In: P. X. Ma, J. Elisseeff, eds. Scaffolding in Tissue Engineering. CRC Press, 2005, pp. 241-251. 
29. Misra S. K., Boccaccini A. R. Biodegradable and bioactive polymer/ceramic composite scaffolds. In: A. R. Boccacini, J. E. Gough, eds. Tissue Engineering Using Ceramics and Polymers. Woodhead Publishing, 2007, pp. 72-92.

30. Huang B., Caetano G., Vyas C., Blaker J., Diver C., Bártolo P. Polymer-Ceramic Composite Scaffolds: The Effect of Hydroxyapatite and $\beta$-tri-Calcium Phosphate. Materials, 2018, vol. 11, iss. 1, pp. 129. https://doi.org/10.3390/ ma11010129

31. Tiwari S., Patil R., Bahadur P. Polysaccharide Based Scaffolds for Soft Tissue Engineering Applications. Polymers, 2018, vol. 11, iss. 1, pp. 1. https://doi.org/10.3390/ polym 11010001

32. Lee K. Y., Jeong L., Kang Y. O., Lee S. J., Park W. H. Electrospinning of polysaccharides for regenerative medicine. Advanced Drug Delivery Reviews, 2009, vol. 61, iss. 12, pp. 1020-1032. https://doi.org/10.1016/j. addr.2009.07.006

33. Spearman B. S., Agrawal N. K., Rubiano A., Simmons C. S., Mobini S., Schmidt C. E. Tunable methacrylated hyaluronic acid-based hydrogels as scaffolds for soft tissue engineering applications. Journal of Biomedical Materials Research Part A, 2020, vol. 108, iss. 2, pp. 279-291. https://doi.org/10.1002/jbm.a.36814

34. Ji Y., Ghosh K., Shu X., Li B., Sokolov J., Prestwich G., Clark R., Rafailovich M. Electrospun three-dimensional hyaluronic acid nanofibrous scaffolds. Biomaterials, 2006, vol. 27, iss. 20, pp. 3782-3792. https://doi.org/10.1016/j. biomaterials.2006.02.037

35. Gonçalves de Pinho A. R., Odila I., Leferink A., van Blitterswijk C., Camarero-Espinosa S., Moroni L. Hybrid Polyester-Hydrogel Electrospun Scaffolds for Tissue Engineering Applications. Frontiers in Bioengineering and Biotechnology, 2019, vol. 7, pp. 231. https://doi. org/10.3389/fbioe.2019.00231

36. Maghdouri-White Y., Petrova S., Sori N., Polk S., Wriggers H., Ogle R., Ogle R., Francis M. Electrospun silk-collagen scaffolds and BMP-13 for ligament and tendon repair and regeneration. Biomedical Physics \& Engineering Express, 2018, vol. 4, iss. 2, pp. 025013. https://doi. org/10.1088/2057-1976/aa9c6f

37. Jia W., Gungor-Ozkerim P. S., Zhang Y. S., Yue K., Zhu K., Liu W., Pi Q., Byambaa B., Dokmeci M. R., Shin S. R., Khademhosseini A. Direct 3D bioprinting of perfusable vascular constructs using a blend bioink. Biomaterials, 2016, vol. 106, pp. 58-68. https://doi. org/10.1016/j.biomaterials.2016.07.038

38. Hardy J. G., Lee J. Y., Schmidt C. E. Biomimetic conducting polymer-based tissue scaffolds. Current Opinion in Biotechnology, 2013, vol. 24, iss. 5, pp. 847-854. https:// doi.org/10.1016/j.copbio.2013.03.011

39. Gerardo-Nava J., Führmann T., Klinkhammer K., Seiler N., Mey J., Klee D., Möller M., Dalton P. D., Brook G. A. Human neural cell interactions with orientated electrospun nanofibers in vitro. Nanomedicine, 2009, vol. 4, iss. 1, pp. 11-30. https://doi.org/10.2217/17435889.4.1.11

40. Yuan J., Shen J., Kang I.-K. Fabrication of protein-doped PLA composite nanofibrous scaffolds for tissue engi- neering. Polymer International, 2008, vol. 57, iss. 10, pp. 1188-1193. https://doi.org/10.1002/pi.2463

41. Mcdonald D., Cheng C., Chen Y., Zochodne D. Early events of peripheral nerve regeneration. Neuron Glia Biology, 2006, vol. 2, iss. 2, pp. 139-147. https://doi. org/10.1017/S1740925X05000347

42. Tomaskovic-Crook E., Gu Q., Rahim S. N. A., Wallace G. G., Crook J. M. Conducting Polymer Mediated Electrical Stimulation Induces Multilineage Differentiation with Robust Neuronal Fate Determination of Human Induced Pluripotent Stem Cells. Cells, 2020, vol. 9, iss. 3, pp. 658. https://doi.org/10.3390/cells9030658

43. Chan E. W. C., Bennet D., Baek P., Barker D., Kim S., Travas-Sejdic J. Electrospun Polythiophene Phenylenes for Tissue Engineering. Biomacromolecules, 2018, vol. 19, iss. 5, pp. 1456-1468. https://doi.org/10.1021/ acs.biomac. 8 b00341

44. Zhou Z., Liu X., Wu W., Park S., Miller II A. L., Terzic A., Lu L. Effective nerve cell modulation by electrical stimulation of carbon nanotube embedded conductive polymeric scaffolds. Biomaterials Science, 2018, vol. 6, iss. 9, pp. 2375-2385. https://doi.org/10.1039/C8BM00553B

45. Huang L., Hu J., Lang L., Wang X., Zhang P., Jing X., Wang X., Chen X., Lelkes P. I., MacDiarmid A. G. Synthesis and characterization of electroactive and biodegradable ABA block copolymer of polylactide and aniline pentamer. Biomaterials, 2007, vol. 28, iss. 10, pp. 1741-1751. https://doi.org/10.1016/j.biomaterials.2006.12.007

46. Lins L. C., Wianny F., Livi S., Hidalgo I. A., Dehay C., Duchet-Rumeau J., Gérard J.-F. Development of Bioresorbable Hydrophilic-Hydrophobic Electrospun Scaffolds for Neural Tissue Engineering. Biomacromolecules, 2016, vol. 17, iss. 10, pp. 3172-3187. https://doi.org/10.1021/ acs.biomac.6b00820

47. Khorshidi S., Solouk A., Mirzadeh H., Mazinani S., Lagaron J. M., Sharifi S., Ramakrishna S. A review of key challenges of electrospun scaffolds for tissue-engineering applications. Journal of Tissue Engineering and Regenerative Medicine, 2016, vol. 10, iss. 9, pp. 715-738. https:// doi.org/10.1002/term.1978

48. Hell A. F., Simbara M. M. O., Rodrigues P., Kakazu D. A., Malmonge S. M. Production of fibrous polymer scaffolds for tissue engineering using an automated solution blow spinning system. Research on Biomedical Engineering, 2018, vol. 34, iss. 3, pp. 273-278. https://doi. org/10.1590/2446-4740.180039

49. Torricelli P., Gioffrè M., Fiorani A., Panzavolta S., Gualandi C., Fini M., Focarete M. L., Bigi A. Co-electrospun gelatin-poly(l-lactic acid) scaffolds: Modulation of mechanical properties and chondrocyte response as a function of composition. Materials Science and Engineering: C, 2014, vol. 36, pp. 130-138. https://doi.org/10.1016/j. msec.2013.11.050

50. Teixeira M. A., Amorim M. T. P., Felgueiras H. P. Poly(Vinyl Alcohol)-Based Nanofibrous Electrospun Scaffolds for Tissue Engineering Applications. Polymers, 2019, vol. 12, iss. 1, pp. 7. https://doi.org/10.3390/ polym 12010007 
51. Sadeghi A., Pezeshki-Modaress M., Zandi M. Electrospun polyvinyl alcohol/gelatin/chondroitin sulfate nanofibrous scaffold: Fabrication and in vitro evaluation. International Journal of Biological Macromolecules, 2018, vol. 114, pp. 1248-1256. https://doi.org/10.1016/j.ijbiomac.2018.04.002

52. Wolf K., te Lindert M., Krause M., Alexander S., te Riet J., Willis A. L., Hoffman R. M., Figdor C. G., Weiss S. J., Friedl P. Physical limits of cell migration: Control by ECM space and nuclear deformation and tuning by proteolysis and traction force. The Journal of Cell Biology, 2013, vol. 201, iss. 7, pp. 1069-1084. https://doi.org/10.1083/ jcb.201210152

53. Akino K., Akita S., Yakabe A., Mineda T., Hayashi T., Hirano A. Human mesenchymal stem cells may be involved in keloid pathogenesis. International Journal of Dermatology, 2008, vol. 47, iss. 11, pp. 1112-1117. https://doi. org/10.1111/j.1365-4632.2008.03380.x

54. Zander N. E., Orlicki J. A., Rawlett A. M., Beebe T. P. Electrospun polycaprolactone scaffolds with tailored porosity using two approaches for enhanced cellular infiltration. Journal of Materials Science: Materials in Medicine, 2013, vol. 24, iss. 1, pp. 179-187. https://doi. org/10.1007/s10856-012-4771-7

55. Torres-Giner S., Gimeno-Alcañiz J. V., Ocio M. J., Lagaron J. M. Optimization of electrospun polylactide-based ultrathin fibers for osteoconductive bone scaffolds. Journal of Applied Polymer Science, 2011, vol. 122, iss. 2, pp. 914-925. https://doi.org/10.1002/app.34208

56. Pei B., Wang W., Fan Y., Wang X., Watari F., Li X. Fiberreinforced scaffolds in soft tissue engineering. Regenerative Biomaterials, 2017, vol. 4, iss. 4, pp. 257-268. https:// doi.org/10.1093/rb/rbx021

57. Rajaram A., Chen X.-B., Schreyer D. J. Strategic Design and Recent Fabrication Techniques for Bioengineered Tissue Scaffolds to Improve Peripheral Nerve Regeneration. Tissue Engineering Part B: Reviews, 2012, vol. 18, iss. 6, pp. 454-467. https://doi.org/10.1089/ten. teb.2012.0006

58. Nandakumar A., Barradas A., de Boer J., Moroni L., van Blitterswijk C., Habibovic P. Combining technologies to create bioactive hybrid scaffolds for bone tissue engineering. Biomatter, 2013, vol. 3, iss. 2, pp. e23705. https:// doi.org/10.4161/biom. 23705

59. Grossemy S., Chan P. P. Y., Doran P. M. Electrical stimulation of cell growth and neurogenesis using conductive and nonconductive microfibrous scaffolds. Integrative Biology, 2019, vol. 11, iss. 6, pp. 264-279. https://doi.org/10.1093/ intbio/zyz022

60. Rodrigues I. C. P., Woigt L. F., Pereira K. D., Luchessi A. D., Lopes É. S. N., Webster T. J., Gabriel L. P. Low-cost hybrid scaffolds based on polyurethane and gelatin. Journal of Materials Research and Technology, 2020, vol. 9, iss. 4, pp. 7777-7785. https://doi.org/10.1016/j. jmrt.2020.04.049

61. Iberite F., Gerges I., Vannozzi L., Marino A., Piazzoni M., Santaniello T., Lenardi C., Ricotti L. Combined Effects of
Electrical Stimulation and Protein Coatings on Myotube Formation in a Soft Porous Scaffold. Annals of Biomedical Engineering, 2020, vol. 48, iss. 2, pp. 734-746. https:// doi.org/10.1007/s10439-019-02397-9

62. Wang J., Tian L., Chen N., Ramakrishna S., Mo X. The cellular response of nerve cells on poly-l-lysine coated PLGA-MWCNTs aligned nanofibers under electrical stimulation. Materials Science and Engineering: $C$, 2018, vol. 91, pp. 715-726. https://doi.org/10.1016/j. msec.2018.06.025

63. Mirzaei E., Ai J., Ebrahimi-Barough S., Verdi J., Ghanbari H., Faridi-Majidi R. The Differentiation of Human Endometrial Stem Cells into Neuron-Like Cells on Electrospun PAN-Derived Carbon Nanofibers with Random and Aligned Topographies. Molecular Neurobiology, 2016, vol. 53, iss. 7, pp. 4798-4808. https://doi.org/10.1007/ s12035-015-9410-0

64. Zhu W., Ye T., Lee S.-J., Cui H., Miao S., Zhou X., Shuai D., Zhang L. G. Enhanced neural stem cell functions in conductive annealed carbon nanofibrous scaffolds with electrical stimulation. Nanomedicine: Nanotechnology, Biology and Medicine, 2018, vol. 14, iss. 7, pp. 2485-2494. https://doi.org/10.1016/j.nano.2017.03.018

65. Rahmani A., Nadri S., Kazemi H. S., Mortazavi Y., Sojoodi M. Conductive electrospun scaffolds with electrical stimulation for neural differentiation of conjunctiva mesenchymal stem cells. Artificial Organs, 2019, vol. 43, iss. 8, pp. 780-790. https://doi.org/10.1111/aor.13425

66. Laforgue A., Robitaille L. Deposition of Ultrathin Coatings of Polypyrrole and Poly(3,4-ethylenedioxythiophene) onto Electrospun Nanofibers Using a Vapor-Phase Polymerization Method. Chemistry of Materials, 2010, vol. 22, iss. 8, pp. 2474-2480. https://doi.org/10.1021/ $\mathrm{cm} 902986 \mathrm{~g}$

67. Wang L., Wu Y., Hu T., Guo B., Ma P. X. Electrospun conductive nanofibrous scaffolds for engineering cardiac tissue and 3D bioactuators. Acta Biomaterialia, 2017, vol. 59, pp. 68-81. https://doi.org/10.1016/j.actbio. 2017.06.036

68. Ghasemi-Mobarakeh L., Prabhakaran M. P., Morshed M., Nasr-Esfahani M. H., Ramakrishna S. Electrical Stimulation of Nerve Cells Using Conductive Nanofibrous Scaffolds for Nerve Tissue Engineering. Tissue Engineering Part A, 2009, vol. 15, iss. 11, pp. 3605-3619. https://doi. org/10.1089/ten.tea.2008.0689

69. Green R. A., Lovell N. H., Wallace G. G., Poole-Warren L. A. Conducting polymers for neural interfaces: Challenges in developing an effective long-term implant. Biomaterials, 2008, vol. 29, iss. $24-25$, pp. 3393-3399. https://doi. org/10.1016/j.biomaterials.2008.04.047

70. Shi G., Rouabhia M., Meng S., Zhang Z. Electrical stimulation enhances viability of human cutaneous fibroblasts on conductive biodegradable substrates. Journal of Biomedical Materials Research Part A, 2008, vol. 84A, iss. 4, pp. 1026-1037. https://doi.org/10.1002/ jbm.a.31337

Поступила в редакцию 03.09.2020, после рецензирования 08.11.2020, принята к публикации 18.11.2020

Received 03.09.2020, revised 08.11.2020, accepted 18.11.2020 